\title{
HUBUNGAN USIA DENGAN PENGETAHUAN DAN PERILAKU PENGGUNAAN SUPLEMEN PADA MAHASISWA INSTITUT TEKNOLOGI SEPULUH NOPEMBER
}

\author{
I Nengah B. S., Ahmad F. A., Chrysella R., Devi Ayu S., Farah K., Fitria, Happy N. E. S., Hieronimus A. \\ N. U., Safiinatunnajah N., Wahyu A. D., Yunita A., Abdul Rahem* \\ Departemen Farmasi Komunitas, Fakultas Farmasi, Universitas Airlangga \\ Gedung Nanizar Zaman Joenoes Kampus C, Jl. Ir. Soekarno, Surabaya 60115, Indonesia \\ E-mail: abdulrahem@ff.unair.ac.id
}

\begin{abstract}
ABSTRAK
Perubahan gaya hidup dan pola konsumsi masyarakat telah menyebabkan peningkatan penggunaan suplemen makanan. Suplemen pada dasarnya dikonsumsi untuk melengkapi nutrisi, bukan untuk menggantikannya. Usia diketahui memiliki pengaruh pada pengetahuan dan perilaku konsumsi suplemen. Tujuan dari penelitian ini adalah untuk mengetahui hubungan usia dengan pengetahuan dan perilaku penggunaan suplemen pada mahasiswa Institut Teknologi Sepuluh Nopember. Pengumpulan data dilakukan pada tanggal 11 September 2019 dengan menggunakan accidental non random sampling untuk 161 responden yang dianalisis menggunakan uji chi-square. Responden dikategorikan menjadi 3 kelompok berdasarkan usia yaitu kurang dari 19 tahun, 19-21 tahun dan diatas 21 tahun. Berdasarkan penelitian ini didapatkan responden terbanyak terdapat pada rentang usia 19-21 (67,7\%), diikuti dengan usia kurang dari 19 tahun $(28,0 \%)$ dan usia diatas 21 tahun (4,3\%). Vitamin C (46,58\%) merupakan suplemen yang paling banyak dikonsumsi, sebagian besar responden tidak dapat menjelaskan cara mendapatkan suplemen yang asli $(37,27 \%)$, responden paling banyak membeli suplemen di apotek $(42,24 \%)$, dan sebanyak 49,07\% responden merasakan efek lebih bugar dan sehat setelah mengonsumsi suplemen. Berdasarkan analisis data, didapatkan hasil bahwa perbedaan usia tidak memengaruhi tingkat pengetahuan dan ketepatan perilaku responden terhadap penggunaan suplemen.
\end{abstract}

Kata kunci: Mahasiswa, Pengetahuan, Perilaku, Suplemen

\begin{abstract}
Changes in lifestyle and consumption patterns have led to increase use of food supplements. Basically, supplements are consumed to compliment nutrients, not to replace them. Age is known to have influence on the knowledge and behavior of supplement consumption. This study aims to determine the relationship of age with knowledge and behavior of supplement use by students of Institut Teknologi Sepuluh Nopember. Data collection was carried out on September 11, 2019 using accidental non random sampling for 161 respondents analyzed using the chi-square test. Respondents were categorized into 3 groups, namely less than 19 years, 19-21 years and over 21 years. From this study it was found that most respondents in the age range of 19-21 (67.7\%), followed ages less 19 years $(28.0 \%)$ and ages over 21 years $(4.3 \%)$. It has found that Vitamin $\mathrm{C}(46.58 \%)$ was the most consumed supplement, most respondents could not explain how to get the original supplement $(37.27 \%)$, the most respondents bought supplements at the pharmacy (42.24\%), and $49.07 \%$ of respondents felt the effects of being fitter and healthier after taking supplements. The result shows that age difference does not affect the level of knowledge and accuracy of respondents' behavior towards the use of supplements.
\end{abstract}

Keywords: Student, Knowledge, Behavior, Supplement 


\section{PENDAHULUAN}

Suplemen kesehatan merupakan produk yang dimaksudkan untuk melengkapi kebutuhan zat gizi makanan atau memperbaiki fungsi kesehatan, mempunyai nilai gizi dan atau efek fisiologis, mengandung satu atau lebih bahan berupa vitamin, mineral, asam amino atau bahan lain bukan tumbuhan yang dapat dikombinasi dengan tumbuhan (BPOM, 2019). Berdasarkan definisi tersebut, maka konsumsi suplemen dimaksudkan untuk melengkapi kebutuhan zat gizi makanan, bukan menggantikannya. Namun, belakangan ini, terjadi perubahan gaya hidup dan pola makan di masyarakat yang dapat disebabkan oleh peningkatan kemakmuran, kemajuan teknologi dan westernisasi. Perubahan ini, banyak terjadi pada remaja yang cenderung menyukai makanan cepat saji yang memiliki sedikit kandungan nilai gizi namun memiliki kalori yang tinggi (Ariska dan Ali, 2019). Hal inilah yang membuat orang banyak mengonsumsi suplemen, karena orang menganggap jumlah mineral dan vitamin yang mereka konsumsi dari makanan yang dikonsumsi tidaklah cukup untuk menjaga tubuh tetap sehat (Chauhan et al. 2017).

Berbagai laporan juga menunjukkan bahwa konsumsi suplemen makanan begitu besar dan akan terus meningkat. Survei yang dilakukan oleh CRN pada tahun 2018 menyatakan bahwa $75 \%$ orang dewasa di Amerika Serikat mengonsumsi suplemen. Dari laporan CRN tersebut, diketahui rentang usia pengguna suplemen yaitu $69 \%$ orang berusia 18-34 tahun, $77 \%$ orang berusia $35-54$ tahun dan $78 \%$ orang berusia diatas 55 tahun. Berdasarkan sebuah penelitian, disebutkan bahwa mahasiswa perguruan tinggi di Amerika Serikat dengan rentang usia 16-23 tahun terindikasi menggunakan suplemen secara teratur dengan persentase sebesar 66\% (Lieberman et al. 2015). Sementara itu, di Indonesia, pertumbuhan konsumsi rumah tangga di bidang kesehatan mengalami peningkatan sebesar 5,28\% (Kementrian Perindustrian RI, 2019). Hal ini mengindikasikan adanya peningkatan pertumbuhan permintaan akan produk kesehatan, termasuk suplemen.

Usia telah terbukti menjadi salah satu faktor utama penggunaan suplemen (O'Brien et al. 2017). Pada penelitian Kolodziej pada tahun 2019, disebutkan bahwa peningkatan usia memengaruhi pengetahuan dalam konsumsi suplemen. Hal ini telah mengindikasikan bahwa usia memengaruhi pengetahuan dan kesadaran akan kesehatan. Usia memengaruhi daya tangkap dan pola pikir seseorang, dimana semakin bertambahnya usia akan semakin berkembang pola pikir dan daya tangkap seseorang sehingga pengetahuan yang diperoleh semakin banyak (Fitriani dan Andriyani, 2015). Penelitian lain juga menyimpulkan bahwa usia dan tingkat pengetahuan memiliki hubungan dengan tingkat perilaku hidup bersih dan sehat, sedangkan pendidikan tidak memiliki hubungan dengan tingkat perilaku hidup bersih dan sehat (Prihanti et al. 2018). Selain itu, perbedaan usia akan mengakibatkan perbedaan selera dan kesukaan terhadap produk sehingga usia merupakan salah satu faktor pribadi yang memengaruhi perilaku konsumen. Perbedaan usia juga memengaruhi perubahan perilaku konsumsi suplemen (Tse et al. 2014).

Namun, masih didapatkan banyak kesalahan dalam penggunaan suplemen. Sedangkan seperti yang diketahui suplemen bukanlah produk yang benar-benar aman untuk semua orang. Seperti obat, suplemen dengan bahan aktif memberikan efek farmakologi yang juga dapat menyebabkan efek samping pada individu yang rentan, sehingga perlu peringatan lebih akan efek samping dan potensi interaksi untuk menghindari masalah kesehatan yang serius (Ronis et al. 2018). Telah dilaporkan dalam uji epidemiologi dan klinis bahwa konsumsi teratur beberapa suplemen makanan dikaitkan dengan peningkatan morbiditas dan mortilitas (Lieberman et al. 2015). Peneliti tertarik untuk melakukan penelitian mengenai hubungan antara usia dengan tingkat pengetahuan dan perilaku penggunaan suplemen pada mahasiswa, karena adanya celah antara pengetahuan dan perilaku sehat pada usia yang relatif matang, dengan realita banyaknya kejadian kesalahan penggunaan suplemen.

\section{METODE PENELITIAN}

\section{Rancangan Penelitian}

Penelitian ini merupakan penelitian analitik observatif yang dilakukan pada tanggal 11 September 2019 di Institut Teknologi Sepuluh Nopember Surabaya.

\section{Sampel dan Teknik Sampling}

Sampel dalam penelitian ini adalah Mahasiswa Institut Teknologi Sepuluh Nopember sebanyak 116 responden dari berbagai fakultas. Data diambil dengan metode accidental non random sampling dengan menggunakan kuesioner semi terbuka yang diisi sendiri oleh responden (self administered questionnaire). 


\section{Variabel}

Variabel yang digunakan yaitu variabel independen berupa usia (X) dan variabel dependen berupa pengetahuan terhadap produk $\left(\mathrm{Y}_{1}\right)$ dan perilaku konsumen $\left(\mathrm{Y}_{2}\right)$ (Tabel 1).

\section{Analisis Data}

Data yang didapatkan dari kuesioner diolah menggunakan program Microsoft Excel dan
SPSS. Analisis data yang penelitian ini dilakukan menggunakan uji chi-square. dilakukan dalam secara statistik

Tabel 1. Variabel yang digunakan dalam penelitian

\begin{tabular}{|c|c|c|c|}
\hline Variabel Independen & Definisi Operasional & Indikator & \\
\hline Usia (X) & $\begin{array}{l}\text { Usia adalah lama waktu } \\
\text { hidup dari seseorang } \\
\text { semenjak dilahirkan } \\
\text { (Kamus Besar Bahasa } \\
\text { Indonesia, 2019) }\end{array}$ & $\begin{array}{l}\text { 1. <19 Tahun } \\
\text { 2. 19-21 Tahun } \\
\text { 3. >21 Tahun }\end{array}$ & \\
\hline Variabel Dependen & Definisi Operasional & Indikator & Subindikator \\
\hline $\begin{array}{l}\text { Pengetahuan terhadap } \\
\text { produk }\left(\mathrm{Y}_{1}\right)\end{array}$ & $\begin{array}{l}\text { Pengetahuan adalah } \\
\text { segala sesuatu yang } \\
\text { diketahui. (Kamus Besar } \\
\text { Bahasa Indonesia, 2019) }\end{array}$ & $\begin{array}{l}\text { Menurut Damanik tahun } \\
\text { 2013, indikator yang } \\
\text { digunakan untuk mengukur } \\
\text { pengetahuan terhadap produk } \\
\text { yaitu: } \\
\text { 1. Atribut produk } \\
\text { 2. Manfaat fisik } \\
\text { 3. Manfaat psikologis } \\
\text { 4. Nilai-nilai }\end{array}$ & $\begin{array}{l}\text { 1. Pengertian suplemen } \\
\text { 2. Kegunaan suplemen } \\
\text { 3. Contoh suplemen } \\
\text { 4. Legalitas suplemen } \\
\text { 5. Cara mengonsumsi } \\
\text { suplemen yang baik dan } \\
\text { benar } \\
\text { 6. Cara menyimpan suplemen. }\end{array}$ \\
\hline $\begin{array}{l}\text { Perilaku Konsumen } \\
\left(\mathrm{Y}_{2}\right)\end{array}$ & $\begin{array}{l}\text { Perilaku adalah tanggapan } \\
\text { atau reaksi individu } \\
\text { terhadap rangsangan atau } \\
\text { lingkungan (Kamus Besar } \\
\text { Bahasa Indonesia, 2019). }\end{array}$ & $\begin{array}{l}\text { Menurut Kotler tahun } 2009 \text {, } \\
\text { indikator dalam mengukur } \\
\text { perilaku konsumen yaitu: } \\
\text { 1. Pengenalan masalah } \\
\text { 2. Pencarian informasi } \\
\text { 3. Penilaian alternatif } \\
\text { 4. Keputusan pemberian }\end{array}$ & $\begin{array}{l}\text { 1. Frekuensi penggunaan } \\
\text { suplemen perhari. } \\
\text { 2. Cara mendapatkan } \\
\text { suplemen. } \\
\text { 3. Hal yang dirasakan } \\
\text { setelah penggunaan } \\
\text { suplemen. }\end{array}$ \\
\hline
\end{tabular}

\section{HASIL DAN PEMBAHASAN}

Pada tanggal 11 September 2019, dilakukan survei di Institut Teknologi Sepuluh Nopember dengan target responden mahasiswa sebanyak 165 orang, tetapi terdapat 4 responden yang tidak mengisi nama suplemen yang digunakan sehingga tidak dapat disimpulkan dan akhirnya digunakan responden sebanyak 161 orang. Pada penelitian, digunakan kuesioner semi terbuka menggunakan metode accidental sampling.

\section{Karakteristik Responden}

Responden penelitian adalah mahasiswa Institut Teknologi Sepuluh Nopember (ITS) di Surabaya sejumlah 161 orang dengan usia yang berbeda. Mayoritas responden adalah mahasiswa pada rentang usia 19-21 tahun sebanyak 109 dari 161 peserta $(67,7 \%)$ (Tabel 2).
Tabel 2. Data Karakteristik Responden

\begin{tabular}{ccc}
\hline \hline Usia & Jumlah & Persentase $(\%)$ \\
\hline$<19$ tahun & 45 & 28,0 \\
$19-21$ tahun & 109 & 67,7 \\
$>21$ tahun & 7 & 4,3 \\
Total & 161 & 100,0 \\
\hline \hline
\end{tabular}

Pemilihan karakteristik responden dalam penelitian ini didasarkan pada suatu penelitian yang menyatakan bahwa mahasiswa dengan strata S1 memiliki rentang usia 18-24 tahun (Hidayatulloh, 2014). Dalam penelitian yang dilakukan oleh Lieberman pada tahun 2015, mahasiswa perguruan tinggi di Amerika Serikat yang dijadikan responden dibagi menjadi 3 kategori yaitu usia 16-19 tahun, 20-22 tahun dan lebih dari 23 tahun. 


\section{Karakteristik Pengetahuan Responden}

Karakteristik pemahaman responden terhadap suplemen meliputi pemahaman tentang pengertian suplemen dan fungsi dari suplemen makanan. Berdasarkan hasil analisis statistik dengan uji chi-square dari data (Tabel 3) dan (Tabel 4) mengenai hubungan usia dengan tingkat pengetahuan responden terhadap suplemen, menunjukkan bahwa perbedaan usia tidak memengaruhi tingkat pengetahuan terhadap suplemen. Hal ini tidak sejalan dengan penelitian Murman pada tahun 2015 yang menyebutkan bahwa usia berpengaruh terhadap fungsi kognitif seseorang. Namun, perbedaan ini terjadi dikarenakan pada penelitian Murman pada tahun 2015 melakukan penelitian pada responden dengan rentang usia 20-80 tahun.

Tidak adanya hubungan antara usia dengan pengetahuan responden terhadap suplemen dapat disebabkan oleh usia responden yang masih dalam usia yang produktif dimana fungsi kognitifnya masih sangat baik, sehingga pengetahuan mengenai suplemen antara responden berusia di bawah 19 tahun hingga di atas 21 tahun cenderung sama.

Tabel 3. Data pengetahuan Pengetahuan Mahasiswa Institut Teknologi Sepuluh Nopember

\begin{tabular}{|c|c|c|c|c|c|c|c|}
\hline \multirow{2}{*}{ No } & \multirow{2}{*}{ Pernyataan } & \multicolumn{6}{|c|}{ Jumlah dan persentase jawaban benar pada usia } \\
\hline & & $<19$ & $\%$ & $19-21$ & $\%$ & $>21$ & $\%$ \\
\hline 1. & $\begin{array}{l}\text { Suplemen makanan adalah produk yang mengandung } \\
\text { satu atau lebih bahan berupa vitamin, mineral, protein } \\
\text { atau bahan lain (berasal dari tumbuhan atau bukan } \\
\text { tumbuhan) yang mempunyai nilai gizi dan atau efek } \\
\text { fisiologis. }\end{array}$ & 44 & 97,78 & 107 & 98,16 & 7 & 100 \\
\hline 2. & $\begin{array}{l}\text { Suplemen makanan adalah produk yang digunakan } \\
\text { untuk mengganti kebutuhan zat gizi dari makanan. }\end{array}$ & 25 & 55,56 & 69 & 63,30 & 4 & 57,14 \\
\hline 3. & $\begin{array}{l}\text { Suplemen makanan adalah produk yang digunakan } \\
\text { untuk melengkapi kebutuhan zat gizi makanan. }\end{array}$ & 44 & 97,78 & 102 & 93,58 & 7 & 100 \\
\hline
\end{tabular}

Tabel 4. Tabulasi Silang Antara Usia dengan Tingkat Pengetahuan Mahasiswa Institut Teknologi Sepuluh Nopember

\begin{tabular}{ccccccccc}
\hline \multirow{2}{*}{ Usia } & \multicolumn{8}{c}{ Pengetahuan } \\
\cline { 2 - 9 } & \multicolumn{2}{c}{ Rendah } & \multicolumn{2}{c}{ Sedang } & \multicolumn{2}{c}{ Tinggi } & \multicolumn{2}{c}{ Total } \\
\cline { 2 - 9 } & $\mathrm{N}$ & $\%$ & $\mathrm{~N}$ & $\%$ & $\mathrm{~N}$ & $\%$ & $\mathrm{~N}$ & $\%$ \\
\hline$<19$ & 1 & 2,22 & 20 & 44,44 & 24 & 53,33 & 45 & 100,00 \\
$19-21$ & 3 & 2,75 & 43 & 39,45 & 63 & 57,80 & 109 & 100,00 \\
$>21$ & 0 & 0,00 & 3 & 42,86 & 4 & 57,14 & 7 & 100,00 \\
\hline \hline
\end{tabular}

Ket:

pengetahuan rendah $=1$ jawaban benar pengetahuan sedang $=2$ jawaban benar pengetahuan tinggi $=3$ jawaban benar $\mathrm{P}=0,957 ; \alpha=0,05$

\section{Karakteristik Perilaku Responden dalam Mengonsumsi Suplemen}

Penentuan karakteristik responden dalam penelitian ini didasarkan pada jawaban jenis suplemen yang dikonsumsi, tujuan penggunaan suplemen sampai bagaimana perilaku responden terhadap cara pengonsumsian dan penyimpanan suplemen tersebut. Berdasarkan rekap data, diperoleh bahwa perilaku pengonsumsian suplemen mayoritas cukup tepat oleh responden dengan usia pada rentang 19-21 tahun sebanyak 50 responden. Seperti halnya di atas, hasil ini juga dipengaruhi oleh banyaknya responden pada rentang usia ini. Grafik dan tabel data karakteristik perilaku responden dalam mengonsumsi suplemen dapat dilihat pada Tabel 5 dan Tabel 6.
Berdasarkan hasil analisis statistik mengenai hubungan usia dengan tingkat perilaku responden terhadap penggunaan suplemen pada tabel 6 dapat ditarik kesimpulan bahwa perbedaan usia antar responden tidak menunjukkan perbedaan bermakna terhadap tingkat kebenaran perilaku responden dalam pengonsumsian suplemen. Hal ini tidak sejalan dengan penelitian yang dilakukan Tse tahun 2014 yang menyatakan bahwa perbedaan usia memengaruhi perubahan perilaku konsumsi suplemen. Tse pada tahun 2014 melakukan penelitian pada responden dengan rentang usia 50-69 tahun dan diatas 70 tahun. Hal ini berbeda dengan rentang usia yang digunakan dalam penelitian ini. 
Tabel 5. Data Perilaku Mahasiswa Institut Teknologi Sepuluh Nopember

\begin{tabular}{|c|c|c|c|c|c|c|c|}
\hline \multirow{2}{*}{ No } & \multirow{2}{*}{ Pernyataan } & \multicolumn{6}{|c|}{ Jumlah dan persentase jawaban benar pada usia } \\
\hline & & $<19$ & $\%$ & $19-21$ & $\%$ & $>21$ & $\%$ \\
\hline 1. & Apa tujuan anda mengonsumsi suplemen? & 32 & 71,11 & 74 & 67,89 & 6 & 85,71 \\
\hline 2. & $\begin{array}{l}\text { Bagaimana anda biasanya menyimpan } \\
\text { suplemen? }\end{array}$ & 17 & 37,78 & 60 & 55,04 & 3 & 42,86 \\
\hline 3. & $\begin{array}{l}\text { Apa efek yang anda rasakan setelah } \\
\text { mengonsumsi sulpemen? }\end{array}$ & 29 & 64,44 & 79 & 72,48 & 5 & 71,43 \\
\hline
\end{tabular}

Tabel 6. Tabulasi Silang Antara Usia dengan Tingkat Perilaku Penggunaan Suplemen Mahasiswa Institut Teknologi Sepuluh Nopember

\begin{tabular}{ccccccccccc}
\hline \hline \multirow{2}{*}{ Usia } & \multicolumn{8}{c}{ Perilaku } \\
\cline { 2 - 11 } & \multicolumn{2}{c}{ Tidak Tepat } & \multicolumn{1}{c}{ Kurang Tepat } & \multicolumn{2}{c}{ Cukup Tepat } & \multicolumn{2}{c}{ Tepat } & \multicolumn{2}{c}{ Total } \\
\cline { 2 - 11 } & $\mathrm{N}$ & $\%$ & $\mathrm{~N}$ & $\%$ & $\mathrm{~N}$ & $\%$ & $\mathrm{~N}$ & $\%$ & $\mathrm{~N}$ & $\%$ \\
\hline$<19$ & 5 & 11,11 & 8 & 17,78 & 26 & 57,78 & 6 & 13,33 & 45 & 100,00 \\
$19-21$ & 4 & 3,67 & 26 & 23,85 & 50 & 45,87 & 29 & 26,61 & 109 & 100,00 \\
$>21$ & 1 & 14,29 & 0 & 0,00 & 4 & 57,14 & 2 & 28,57 & 7 & 100,00 \\
\hline \hline
\end{tabular}

Ket:

perilaku tidak tepat $=0$ jawaban benar

perilaku kurang tepat $=1$ jawaban benar

perilaku cukup tepat $=2$ jawaban benar

perilaku tepat $=3$ jawaban benar

$\mathrm{P}=0,151 \alpha=0,05$

\section{Jenis Suplemen yang Dikonsumsi oleh Responden}

Berdasarkan hasil pengolahan data (Tabel 7), dapat diketahui bahwa 161 mahasiswa ITS pernah atau sedang mengonsumsi berbagai jenis suplemen. Jenis suplemen yang paling banyak dikonsumsi mahasiswa ITS yaitu Vitamin C sebanyak 46,58\%. Dalam penelitian Lieberman tahun 2015, diketahui jenis suplemen yang dikonsumsi yaitu $42 \%$ multivitamin, atau multimineral, $17 \%$ vitamin $\mathrm{C}, 17 \%$ protein/asam amino, dan $13 \%$ kalsium. Hasil penelitian Lieberman pada tahun 2015 tidak sejalan dengan data yang diperoleh dalam penelitian ini dimana mayoritas jenis suplemen yang dikonsumsi adalah vitamin $\mathrm{C}$ dengan persentase sebesar $46,58 \%$.

Tabel 7. Jenis suplemen yang dikonsumsi Mahasiswa Institut Teknologi Sepuluh Nopember

\begin{tabular}{|c|c|c|c|}
\hline $\mathrm{No}$ & Jenis Suplemen & Jumlah & Persentase (\%) \\
\hline 1 & Herbal & 54 & 24,66 \\
\hline 2 & Vitamin $\mathrm{C}$ & 102 & 46,58 \\
\hline 3 & Multivitamin & 39 & 17,81 \\
\hline 4 & Mineral & 3 & 1,37 \\
\hline 5 & Asam amino & 10 & 4,57 \\
\hline 6 & Multivitamin dan mineral & 11 & 5,02 \\
\hline
\end{tabular}

Ket: terdapat beberapa responden yang mengonsumsi lebih dari satu suplemen.

Cara Responden Mengetahui Keaslian Produk Suplemen

Pada Tabel 8 disajikan data mengenai tingkat cara mengetahui keaslian penggunaan suplemen 161 mahasiswa Institut Teknologi Sepuluh Nopember. Tingkat pengetahuan yang dimaksud adalah mengenai kemampuan responden dalam membedakan suplemen yang asli atau palsu, ditunjukkan bagaimana responden dapat menjelaskan dimana mendapatkan informasi mengenai keaslian suplemen. Berdasarkan data yang didapatkan, mayoritas responden mengetahui keaslian suplemen dengan cara melihat pada kemasan maupun membeli di apotek dengan harapan dapat bertanya kepada apoteker bertugas. 
Tabel 8. Cara Mahasiswa Institut Teknologi Sepuluh Nopember Mengetahui Keaslian Suplemen

\begin{tabular}{clcc}
\hline \hline No & \multicolumn{1}{c}{ Cara Mengetahui Keaslian Suplemen } & Frekuensi (n) & Persentase $(\%)$ \\
\hline 1 & Kemasan & 43 & 26,61 \\
2 & Beli di apotek & 43 & 26,61 \\
3 & Beli di produsen/distributor & 4 & 2,48 \\
4 & Informasi di Internet & 2 & 1,24 \\
5 & Tanya orang lain & 9 & 5,59 \\
6 & Tidak bisa menjelaskan & 60 & 37,27 \\
\hline \multicolumn{2}{r}{ Total } & 161 & 100 \\
\hline
\end{tabular}

\section{Tempat Responden Mendapatkan Suplemen}

Pada Tabel 9 disajikan data mengenai tempat 161 mahasiswa Institut Teknologi Sepuluh Nopember tempat mendapatkan suplemen. Tempat mendapatkan suplemen meliputi rumah sakit, apotek, toko obat, supermarket dan lainnya. Berdasarkan data yang telah diperoleh, dapat disimpulkan bahwa tempat mendapatkan suplemen terbanyak oleh mahasiswa ITS adalah di apotek dengan persentase $42,24 \%$.

Tabel 9. Tempat Mahasiswa Institut Teknologi Sepuluh Nopember Mendapatkan Suplemen

\begin{tabular}{|c|c|c|c|c|c|}
\hline No & \multicolumn{2}{|l|}{ Nama } & Jumlah responden & \multicolumn{2}{|c|}{ Persentase $(\%)$} \\
\hline 1 & \multicolumn{2}{|l|}{ Rumah Sakit, Apotek } & 6 & \multicolumn{2}{|l|}{3,73} \\
\hline 2 & \multicolumn{2}{|l|}{ Rumah Sakit, Apotek, Toko Obat } & 1 & \multicolumn{2}{|l|}{0,62} \\
\hline 3 & \multicolumn{2}{|l|}{ Rumah Sakit, Apotek, Toko Obat, Supermarket } & 6 & \multicolumn{2}{|l|}{3,73} \\
\hline 4 & \multicolumn{2}{|l|}{ Rumah Sakit, Apotek, Toko Obat, Supermarket, Lainnya } & 1 & \multicolumn{2}{|l|}{0,62} \\
\hline 5 & \multicolumn{2}{|l|}{ Rumah Sakit, Apotek, Supermarket } & 1 & \multicolumn{2}{|l|}{0,62} \\
\hline 6 & \multicolumn{2}{|l|}{ Rumah Sakit, Supermarket } & 1 & \multicolumn{2}{|l|}{0,62} \\
\hline 7 & \multicolumn{2}{|l|}{ Apotek } & 68 & \multicolumn{2}{|l|}{42,24} \\
\hline 8 & \multicolumn{2}{|l|}{ Apotek, Toko Obat, Supermarket } & 12 & \multicolumn{2}{|l|}{7,45} \\
\hline 9 & \multicolumn{2}{|l|}{ Apotek, Toko Obat, Lainnya } & 1 & \multicolumn{2}{|l|}{0,62} \\
\hline 10 & \multicolumn{2}{|l|}{ Apotek, Supermarket } & 14 & \multicolumn{2}{|l|}{8,70} \\
\hline 11 & \multicolumn{2}{|l|}{ Toko Obat } & 11 & \multicolumn{2}{|l|}{6,83} \\
\hline 12 & \multicolumn{2}{|l|}{ Toko Obat, Supermarket } & 2 & \multicolumn{2}{|l|}{1,24} \\
\hline 13 & \multicolumn{2}{|l|}{ Supermarket } & 25 & \multicolumn{2}{|l|}{15,53} \\
\hline 14 & \multicolumn{2}{|l|}{ Lainnya } & 12 & \multicolumn{2}{|l|}{7,45} \\
\hline \multicolumn{3}{|c|}{ Total } & 161 & \multicolumn{2}{|l|}{100,00} \\
\hline \multirow{2}{*}{\multicolumn{6}{|c|}{$\begin{array}{c}\text { Ket: Lainnya berupa pembelian mela } \\
\text { Efek yang Dirasakan Responden Setelah }\end{array}$}} \\
\hline & & $\underline{\mathrm{Tat}}$ & oel 10. Efek Penggunaan Supl & lemen & \\
\hline$M e$ & onsumsi Suplemen & No & Efek yang dirasakan & Jumlah & Persentase \\
\hline & fek yang dirasakan para mahasiswa Institut & & Merasa lebih bugar dan sehat & 79 & $49,07 \%$ \\
\hline Tek & ologi Sepuluh Nopember selaku responden & & Tidak mudah lelah & 11 & $6,83 \%$ \\
\hline & $\begin{array}{l}\text { rung beragam (1abel 10). Efek terbesar } \\
\text { dirasakan oleh para responden karena }\end{array}$ & & Memperbaiki pola makan & 6 & $3,73 \%$ \\
\hline pen & gunaan suplemen adalah merasa lebih & & Menambah tinggi badan & 1 & $0,62 \%$ \\
\hline & $\begin{array}{l}\text { dan sehat }(49,07 \%) \text {. Namun, penggunaan } \\
\text { men memberikan efek yang berbeda untuk }\end{array}$ & & $\begin{array}{l}\text { Meningkatkan imunitas } \\
\text { tubuh }\end{array}$ & 16 & $9,94 \%$ \\
\hline tiap & esponden. Hal ini menandakan bahwa efek & & Tidak terasa & 43 & $26,71 \%$ \\
\hline atau & respon yang dirasakan cenderung & & Lain-lain & 5 & $3,11 \%$ \\
\hline & riasi antar individu. Salah satu dasar yang & & Total & 161 & $100,00 \%$ \\
\hline
\end{tabular}
melatarbelakangi perbedaan respon antar individu adalah dasar genetik. Selain itu, lingkungan, diet, usia, gaya hidup dan kondisi kesehatan individu juga dapat memengaruhi respon seseorang.

Ket: Lain-lain berupa melancarkan buang air kecil dan tidak mengisi jawaban. 


\section{UCAPAN TERIMA KASIH}

Ucapan terima kasih kami sampaikan kepada semua pihak yang telah banyak membantu baik secara langsung maupun tidak langsung sehingga penelitian ini dapat terlaksana dengan baik.

\section{DAFTAR PUSTAKA}

Ariska DW, Ali MS 2019, 'Pengaruh kebiasaan konsumsi junk food terhadap kejadiaan obesitas remaja', Jurnal Kesehatan Surya Mitra Husada, 1(1), pp. 1-7.

Badan Pengawas Obat dan Makanan 2019, Peraturan Badan pengawas Obat dan Makanan Republik Indonesia Nomor 17 Tahun 2019 tentang Persyaratan Mutu Suplemen Kesehatan, BPOM, Jakarta

Bailey RL, Fulgoni III VL, Keast DR, Dwyer JT 2011, 'Dietary supplement use is associated with higher intakes of minerals from food sources', The American journal of clinical nutrition, 94(5), pp. 1376-1381.

Bailey RL, Fulgoni III VL, Keast DR Dwyer JT 2012, 'Examination of vitamin intakes among US adults by dietary supplement use', Journal of the Academy of Nutrition and Dietetics, 112(5), pp. 657-663.

Bailey RL, Gahch JJ, Miller PE, Thomas PR, Dwyer JT 2013, 'Why US adults use dietary supplements', JAMA internal medicine, 173(5), pp. 335-361.

Chauhan HA, Bhatia M, Hirpara N 2017, 'Dietary food supplements : what consumers perceive ?' Making Difference and Becoming the Agents of Change in the Field of Management, 1(1), pp. 100-110.

Damanik ER 2013, 'Bagaimana product knowledge dan product involvement memotivasi konsumen?', Humaniora, 4(2), pp. 1336-1344.

Fitriani NL, Andriyani S. 2015, 'Hubungan antara pengetahuan dengan sikap anak usia sekolah akhir (10-12 tahun) tentang makanan jajanan di sd negeri ii tagog apu padalarang kabupaten bandung barat tahun 2015', Jurnal Pendidikan Keperawatan Indonesia, 1(1), pp. 7-26.

Gahche JJ, Bailey RL, Potischman N, Dwyer JT 2017, 'Dietary supplement use was very high among older adults in the United States in 2011-2014'The Journal of nutrition, 147(10), pp. 1968-1976.

Hidayatulloh LI 2014, 'Optimalisasi fungsi pembimbing akademik bagi sukses studi mahasiswa (studi empiris pada Fakultas Agama Islam Universitas Muhammadiyah Surakarta angkatan 2011)' Skripsi, Universitas Muhammadiyah Surakarta.

Kementrian Perindustrian RI 2019, Analisis Perkembangan Industri Edisi I, Pusdatin Kemenperin, Jakarta.

Kołodziej G, Cyran-Grzebyk B, Majewska J, Kołodziej K 2019, 'Knowledge concerning dietary supplements among general public', BioMed Research International, 2019, pp. $1-12$.

Kotler P 2009, Marketing Management, Prentice-Hall Publication, New Jersey.

Lieberman HR, Marriott BP, Williams C, Judelson DA, Glickman EL, Geiselman PJ, Dotson L, Mahoney CR 2015, 'Patterns of dietary supplement use among college students', Clinical Nutrition, 34(5), pp. 976985.

Murman DL 2015, 'The impact of age on cognition'. Seminars in hearing: Thieme Medical Publishers, 36(3), pp. 111-121.

O'Brien SK, Malacova E, Sherriff JL, Black LJ 2017, 'The prevalence and predictors of dietary supplement use in the australian population' Nutrients, 9(10), pp. 1-9.

Pengetahuan 2016, Pada KBBI Daring, viewed 29 September 2019, https://kbbi.kemdikbud.go.id/entri/pengetah uan

Perilaku 2016, Pada KBBI Daring, viewed 29 September 2019, https://kbbi.kemdikbud.go.id/entri/perilaku

Prihanti GS, Lista DA, Habibi R, Arsinta II, Hanggara SP, Galih RP, Sinta F 2018, 'Faktor-faktor yang mempengaruhi tingkat perilaku hidup bersih dan sehat pada tatanan rumah tangga di wilayah kerja puskesmas poned x', Saintika Medika, 1(1), pp. 7-14.

Ronis MJJ, Pedersen KB, Watt J 2018, 'Adverse effects of nutraceuticals and dietary supplements', Annual Review of Pharmacology and Toxicology, 58, pp. 583601.

Tse M, Chan KL, Wong A, Tam E, Fan E, Yip G 2014, 'Health supplement consumption behavior in the older adult population: An exploratory study' Frontiers in Public Health, 12(11), pp. 1-7.

Usia 2016, Pada KBBI Daring, viewed 29 September 2019 , https://kbbi.kemdikbud.go.id/entri/usia 